\title{
The following Presents to the Library have been received, for which the Society tenders its grateful thanks.
}

1. Bulletin of the American Mathematical Society.

2. Annals of Mathematics.

3. Bulletin of the Calcutta Mathematical Society.

4. Proceedings of the Cambridge Philosophical Society.

5. Proceedings of the Royal Society of Edinburgh.

6. Bulletin de la Société Mathématique de France.

7. Journal of the Indian Mathematical Society.

8. Proceedings of the London Mathematical Society.

9. Revista de la Real Academia de Ciencias de Madrid.

Io. The Mathematical Gazette.

I . The Mathematics Teacher.

12. Rendiconti der Circolo Matematico di Palermo.

13. Contribucion al Estudio de la Ciencias Fisicas y Matémáticas ; presented by the Universidad National de la Plata.

14. Revue Semestrielle des Publications Mathématiques.

15. The Tôhoku Mathematical Journal.

16. Science Reports of the Tôhoku Imperial University.

17. Journal of the College of Science, Imperial University of Tôkyô.

18. Proceedings of the Tôkyô Mathematico. Physical Society.

19. Proceedings of the National Academy of Sciences of the United States.

20. Vierteljahrsschrift dor Naturforschenden Gesellschaft, Zürich.

21. American Journal of Mathematics.

22. Proceedings of the American Philosophical Society.

23. Nouvelles Annales de Mathématiques.

24. Revista de Mathematicos y Fisicas Elementales.

25. Annales de la Faculté des Sciences de l'Université de Toulouse.

26. Wiskundige Opgaven.

27. Bulletin of the University of Kansas.

28. Memoirs and Proceedings of the Manchester Literary and Philosophical Society.

29. Sitzungsberichte der Koniglich Bayerischen Akademie der Wissenschaften Mathematisch-Physikalische Klasse., 
3o. Nova Acta Regiae Societatis Scientiarum Upsaliensis.

3r. Géométrie Synthétique des Unicursales de Trosième Classe et de Quatrième Ordre, par E. Bally.

32. Précis de Calcul Géométrique, par R. Leveugle.

33. Leģons sur les Fonctions Automorphes, par Georges Giraud.

34. Fundimenta Mathematicae, Tom I., II.

35. Bulletin de l'Institut Aérodynamique de Koutchino.

36. Table de Caractéristiques de Base 3003o, par ERnest Lebon.

37 Resolutio Aequationis Generalis Dimensions N., von Dr med. O. Everts.

38. (I) Latitude Developments connected with Geodesy and Cartography,

(2) A Study of Map Projections in General,
by Oscar S. Adams

39. Acta Academiae Aboensis, Humaniora 1 .

40. Géométrie et Analyse des Intégrals doubles, par A. BuHL.

41. Post-Graduate Teaching in the University of Calcutta (1919-20).

42. (I) The Eliminant of two Binary Quantics with Determinantal Coefficients.

(2) Note on the $m^{\text {th }}$ Compound of a Determinant of the ( $\left.3 m\right)^{\text {th }}$ order.

(3) Note on the Determinant whose Matrix is the sum of Two Clrculant Matrices.

(4) Second Note on the Determinant of the sum of Two Circulant Matrices

(5) Note on Pfaffians with Polynomial Elements.

(6) Note on Certain Determinant Identities arrived at by $\mathrm{H}$. v. КосH.

(7) Note on Unimodular and other Persymmetric Determinants.

(8) Note on a Sum of Products which involves symmetrically the $N^{\text {tb }}$ roots of I.

(9) A Seventh List of Writings on Determinants, by Sir THomas Muir, LL. D.

43. Vector Calculus, by Durgaprasanna Bhattacharyya, M.A.

44. Fermat's Last Theorem, by M. Cashmore.

45. Publications de l'Institut de Mathematiques de l'Université de Strasbourg, Vol. I. (1920).

46. Theory of Sonics, Vol. I., by George Constantinesco.

47. Dorman Wave.Power Tools.

48. Nuevos Teoremas Que Resuelven el Problema De Hurwitz, par José IsaAc Corral. 